\title{
ON THE MECHANISM OF NEPHROTIC EDEMA
}

\author{
BY ROBERT F. LOEB, DANA W. ATCHLEY, DICKINSON W. \\ RICHARDS, JR., ETHEL M. BENEDICT AND MARY E. DRISCOLL \\ (From the Department of Medicine, College of Physicians and Surgeons, Columbia Univer- \\ sity, and The Presbyterian Hospital, New York)
}

(Received for publication February 15, 1932)

\section{INTRODUCTION}

The study of factors responsible for the development of edema in various disease conditions has led to the accumulation of much valuable data, but a fundamental understanding of the physicochemical processes remains to a large extent obscure. Furthermore, a correlation of the mechanisms that are understood has perhaps been delayed by the tendency of various groups of investigators to overemphasize a single mechanism. The confusion is probably greatest in that type of edema seen most frequently in chronic nephritis or nephrosis ${ }^{1}$ and also in that known as "nutritional edema."

The edema of chronic nephritis has been explained by one group of investigators upon the hypothesis that renal or tissue defects interfere with the elimination of certain electrolytes and by another group upon the theory that the fundamental disturbance is a decrease in the protein content of the blood serum. The chief exponents of the former school of thought are Widal (1), who pointed out the apparent inability of the kidney to excrete the chloride ion, and Magnus-Levy $(2,3)$, Leon Blum and his pupils (4) and Falta (5), who have emphasized the apparent inability of the kidney to excrete sodium in the presence of nephrotic edema. In 1896 Starling (6) opened the way for the alternative concept when he pointed out that if the osmotic pressure of the blood serum in the capillaries fell below the hydrostatic pressure, fluid would be forced into the tissue spaces and consequently could not be absorbed. This idea was first applied to the mechanism of edema in renal disease by Epstein (7) in his studies of nephrosis. In the past decade, as a result of extensive studies, Peters and his co-workers (8) have extended this concept and have shown the striking parallelism between the protein content of the serum and a tendency to the development of edema. They have shown that this relationship holds not only for nephrotic but also for nutritional edema where there is no reason to assume the presence of

\footnotetext{
"In this paper the expression "nephrotic edema" will be applied to that type of edema found in patients suffering either from true lipoid nephrosis or the so-called nephrotic form of chronic glomerular nephritis.
} 
kidney damage. Their findings are in accord with the careful observations of Govaerts (9) and of Schade (10) and also receive confirmation in the recent work of Leiter (11), Barker and Kirk (12), Weech and Ling (13), Paul Meyer (14) and many others.

While the general parallelism between the presence of edema and decrease in the concentration of protein in the blood with its accompanying abnormality in the ratio, albumin/globulin, is striking, certain factors disturbing to the assumption of a simple causal relationship have been encountered. In 1923, the writers (15) found that edema of the nephrotic type might disappear completely without change in the concentration of proteins in the blood. Since that time Van Slyke and associates (16) and others have observed the same phenomenon. Paul Meyer (14) has gone a step further and found that edema of this type may disappear while the "colloidal" osmotic pressure of the serum actually diminishes significantly, whereas a rise would naturally be anticipated according to the osmotic hypothesis. Unless, therefore, there is a striking drop in the hydrostatic pressure in the venous limbs of the capillaries in these cases, which does not seem likely, it is difficult to explain the process of edema on the basis of low serum protein alone. Other facts difficult to explain on this purely osmotic basis are the experiments of Magnus-Levy and of L. Blum, which suggest that there is specific retention of sodium but not of potassium in certain edematous individuals. From a purely osmotic or hydrostatic viewpoint, one would anticipate approximately equal retention of any monovalent ion with water. This specific sodium retention in nephritis has been frequently attributed to local kidney damage. On the other hand in nutritional edema it is difficult to conceive of the presence of local kidney changes and yet in this condition disturbances of water and electrolyte excretion similar to those present in nephrosis are encountered.

In view of this contradictory state of our knowledge, it has seemed worth while to study in prolonged and carefully controlled balance experiments, the response to the ingestion of various electrolytes in a patient with nephrotic edema and to contrast the behavior of this individual with the normal under similar circumstances.

\section{METHODS}

The methods employed for the determination of chloride, total base (except that in the stool, food, and urine when the calcium was higher than normal, the calcium was removed and sodium, potassium and magnesium determined together), carbon dioxide capacity, nonprotein nitrogen, phosphates, total nitrogen and hematocrit are described in an earlier paper (24). The calcium content of serum, urine and stool was determined by the method of Clark and Collip (25). Potassium was determined by the method of Tisdall and Kramer (26) with the exception that the serum was ashed and that in the urine determinations $1 \mathrm{cc}$. was ashed, made up to a volume of $10 \mathrm{cc}$. and 2 cc. aliquots 
analyzed. Organic acids were determined by the method of Van Slyke and Palmer (27). Ketones were determined by Van Slyke's method (28) and creatinine by Folin's method (29). For oxygen capacity the method of Van Slyke and Neill (30) was employed. Sugar was determined by the method of Folin and $\mathrm{Wu}(31)$. Inorganic sulfates were estimated by Fiske's method (32) with the following alteration: in the removal of phosphate the magnesium carbonate was added before instead of after making up to volume; $15 \mathrm{cc}$. to $20 \mathrm{cc}$. of filtrate were used, which after precipitation were centrifuged for 20 minutes (2000 r.p.m.) instead of being filtered. The precipitate was washed by adding one cc. of 95 per cent acetone and mixing with a glass rod which was washed with $3 \mathrm{cc}$. of acetone and centrifuged for 20 minutes. This was repeated twice, $5 \mathrm{cc}$. of water were added to the precipitate which was heated in a water bath until all odor of acetone was gone. Titratable acids were determined as follows: a standard of $10 \mathrm{cc}$. of $\mathrm{M} / 5$ phosphate buffer mixture at $\mathrm{pH} 7.4$ plus three drops of 0.5 per cent aqueous neutral red was used; 10 cc. of urine in a $200 \mathrm{cc}$. volumetric flask with three drops of 0.5 per cent neutral red were titrated with $\mathrm{N} / 10$ sodium hydroxide and reported as milliequivalents of acid per twenty-four hours. The base bound to phosphate was calculated according to Gamble, Ross and Tisdall (33), and base bound to protein according to Van Slyke, Wu and McLean (34).

\section{PART I. THE STUDY OF A PATIENT WITH NEPHROTIC EDEMA}

\section{Details of the experiment}

A. G., number 293241. The patient was an American born Jewish boy of 21 whose family and past history were entirely negative except for the fact that his mother has hypertension. Without any preceding infection, three months before admission the patient complained of mild generalized pruritus for a week and this was followed by the gradual development of massive edema of the face, abdomen, genitalia and legs, for which the patient sought relief after eleven weeks at home. Physical examination including the eye grounds was entirely negative except for the edema. Blood pressure was $122 / 88$. The urine always showed a heavy trace of albumin, specific gravity varied between 1.012 and 1.030. The sediment contained granular and hyalin casts most of the time and very occasionally a few red blood cells. On admission his phthalein excretion was 40 per cent. Routine blood counts and hemoglobin were normal. The blood Wassermann reaction was negative. During his stay of four and one half months in the hospital, the blood serum protein varied between 3.2 and 3.7 per cent, blood urea between 0.71 and 0.23 grams per liter, cholesterol between 440 and $233 \mathrm{mgm}$. per $100 \mathrm{cc}$., blood calcium between 8.8 and $9.5 \mathrm{mgm}$. per $100 \mathrm{cc}$. The blood phosphorus was $4.8 \mathrm{mgm}$. per $100 \mathrm{cc}$. The basal metabolism varied between -26 and -7 per cent. The blood chloride varied between 100 and $119 \mathrm{~m}$. eq. per liter depending more or less on the type of therapy being employed. While in the hospital he was given a diet high in protein and containing less than 2.0 grams of $\mathrm{NaCl}$ a day. He received many types of therapy, most of which were totally ineffectual in bringing about a diuresis. Thyroid extract was gradually increased to 1.80 grams daily without symptoms. Coincidently with this thyroid administration and the ingestion of 12.0 grams of $\mathrm{NH}_{4} \mathrm{Cl}$ daily the patient gradually lost 42 pounds. This diuresis was not accompanied by any significant change in the concentration of protein in the blood serum. On admission the serum protein concentration was 3.5 per cent and after diuresis it was 3.7 per cent. 
Second admission. Four weeks after his discharge from the hospital, the patient was readmitted to the hospital, having gained 32 pounds in spite of the daily ingestion of 8.0 grams of $\mathrm{NH}_{4} \mathrm{Cl}$ on alternate weeks. Physical examination was again essentially negative, except for massive edema. His urinary findings were unchanged and his blood count showed no significant abnormality. The serum protein concentration was 3.5 per cent, the blood cholesterol was $356 \mathrm{mgm}$. per cent, his blood chloride concentration was 110 m. eq. per liter (probably effect of daily ingestion of $\mathrm{NH}_{4} \mathrm{Cl}$ ) and the blood urea was 0.41 gram per liter. His basal metabolic rate was -27 per cent.

On admission, all medication was stopped, the patient was given a high protein diet containing less than 2.0 grams of $\mathrm{NaCl}$ a day. He remained in bed during the entire period of experimental observation. On September 21, ten days after admission, a still more carefully controlled regime was instituted. The patient was placed on a standard diet of 80 grams of protein and enough carbohydrate and fat were added to make a daily intake of 2000 calories and to yield a neutral ash. The mineral content of the diet was calculated to contain the following amount daily: $\mathrm{K}=76.5 \mathrm{~m}$. eq., $\mathrm{Na}=29.8 \mathrm{~m}$. eq., $\mathrm{Ca}$ $=20.5 \mathrm{~m}$. eq., $\mathrm{Mg}=19.5 \mathrm{~m}$. eq., $\mathrm{Cl}=19.6 \mathrm{~m}$. eq. and $\mathrm{P}=65.0 \mathrm{~m}$. eq. calculated at $\mathrm{pH}$ 7.0. The patient ate identical meals every day of the period of observation and was given $1000 \mathrm{cc}$. of fluid in addition to the water of the food. The patient ate his entire quota of food every day and there was never any diarrhea. The observations were carried on in the autumn and no visible sweating occurred.

The studies on this patient were limited chiefly to the urinary response to the ingestion of the chlorides of potassium, sodium, ammonium and calcium. Observations were made on the blood from time to time, the samples being taken without the use of the tourniquet and delivered under oil. When calcium chloride was given the loss of these two ions in the feces was determined. All analyses were made in duplicate. The $\mathrm{pH}$ of the urine, titratable acid and $\mathrm{NH}_{3}$ were determined daily. Total fixed base, potassium and chlorine were determined for periods varying from two to four days, as may be seen in Table 1. In the last two periods calcium was determined in the urine. In the other periods $\mathrm{Na}, \mathrm{Mg}$ and $\mathrm{Ca}$ were estimated together by the difference between total fixed base and potassium. This seemed a justifiable procedure, as the amounts of these three ions formed, in most instances, only a small fraction of the total base excreted.

\section{RESULTS}

In the foreperiod which consisted of twelve days divided into units of three days each there were only minor fluctuations in the excretion of total inorganic base, $\mathrm{K}, \mathrm{Na}+\mathrm{Mg}+\mathrm{Ca}$ as determined by difference, $\mathrm{Cl}$, and $\mathrm{NH}_{3}$. These constant rates of excretion obtained particularly after the third day, as may be seen in Figure 1 and Table 1. There were distinct fluctuations in the urine $\mathrm{pH}$ and titratable acid indicative of irregularity in phosphate excretion and possibly of varying degrees of proteinuria. There were also fluctuations in the excretion of nitrogen.

Effect of the ingestion of $\mathrm{KCl}$. During the two days of period $\mathrm{V}$ the patient was given $260 \mathrm{~m}$. eq. of $\mathrm{KCl}$ with marked changes in the composition of the urine. There was a drop in the excretion of $\mathrm{NH}_{3}$, the titratable acid decreased strikingly with a coincident increase in the $\mathrm{pH}$. These 
changes appear to be explained by the interesting fact that 66 per cent of the ingested potassium was excreted in these days while only 35 per cent of the extra $\mathrm{Cl}$ was eliminated. On the first day of period VI, 37 m. eq. of $\mathrm{KCl}$ were ingested and then $\mathrm{KCl}$ administration was stopped. In this period (see Table 1 and Figure 1) the urine $\mathrm{pH}$ went down, the titratable acid increased and there was a sustained increase in the $\mathrm{NH}_{3}$ excretion accompanied perhaps by a slight increase in the base fraction $\mathrm{Na}+\mathrm{Mg}+\mathrm{Ca}$. This behavior of the urine may find its explanation

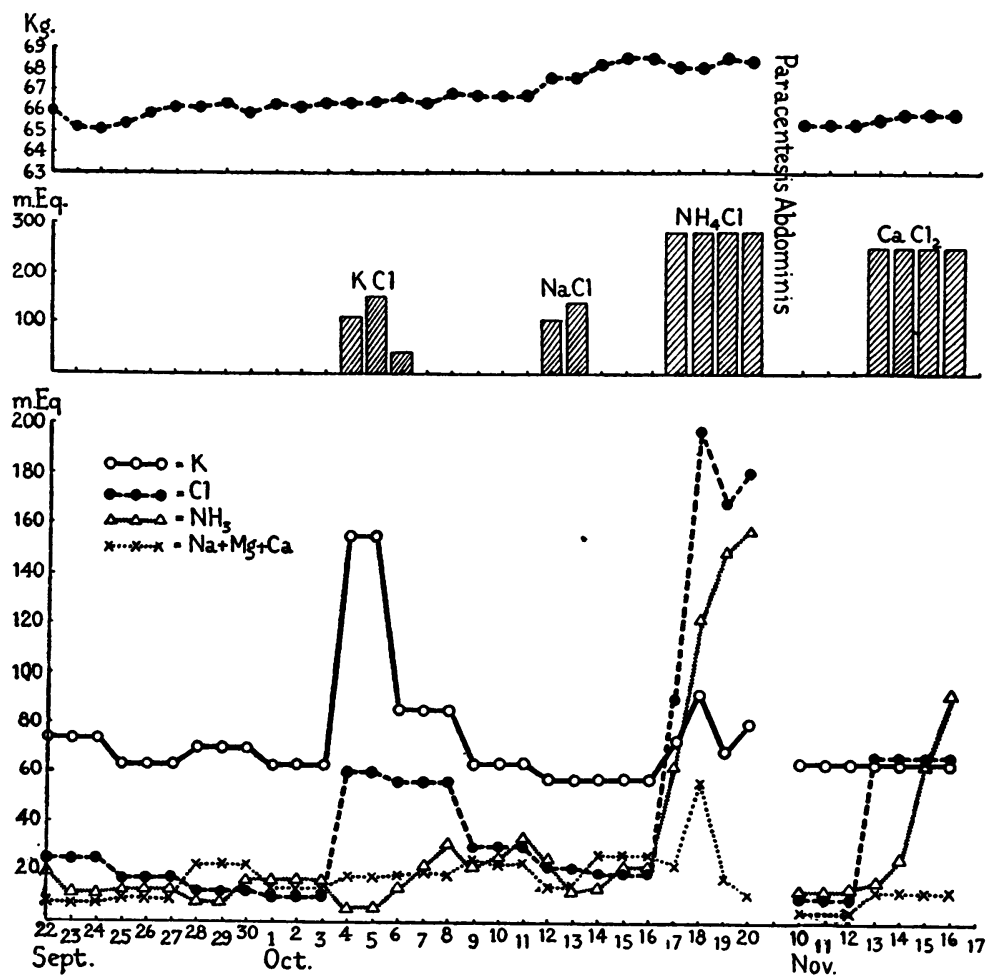

Fig. 1. Urinary Response of the Nephrotic Patient to the Ingestion of Various Electrolytes

in the fact that during these three days only 17 per cent of the total $\mathrm{K}$ added to the diet was excreted whereas 43 per cent of the chlorine passed through the kidneys. In other words, the reaction resembled that of the body to the ingestion of $\mathrm{HCl}$ or an "acid salt." No diuresis resulted in this patient from this short period of $\mathrm{KCl}$ administration.

Effect of the ingestion of $\mathrm{NaCl}$. During the two days of period VIII the patient was given $246 \mathrm{~m}$. eq. of $\mathrm{NaCl}$. This was quantitatively retained by the body as is strikingly shown in Figure 1 . There was no apparent effect on the rate of excretion of $\mathrm{NH}_{3}$, titratable acid, $\mathrm{Na}+\mathrm{Mg}$ 


\begin{tabular}{|c|c|c|c|c|c|c|c|}
\hline & & & & & 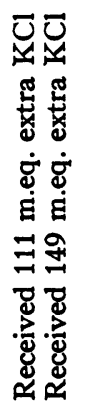 & 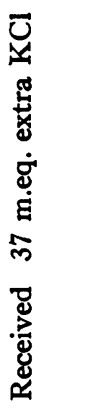 & \\
\hline 范 & 寒 & @्ञ & 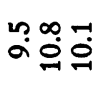 & 윰뭉 & s. & 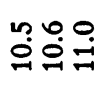 & $\stackrel{m}{=} \underset{\exists}{=} \stackrel{\infty}{=}$ \\
\hline 题 & 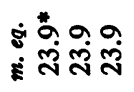 & *ี่ & 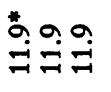 & 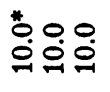 & 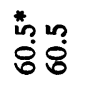 & 苟 & ثัँ \\
\hline 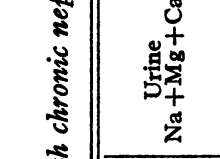 & 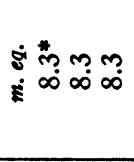 & 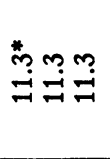 & 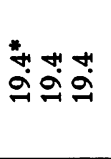 & $\stackrel{*}{\infty} \stackrel{\infty}{\sim} \underset{\sim}{\stackrel{\sim}{\sim}}$ & 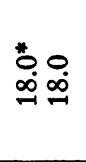 & 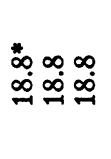 & लें \\
\hline 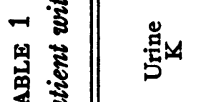 & 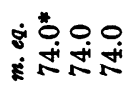 & ิํำสิ์ & 울영요 & 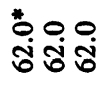 & 究 & 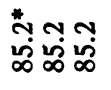 & $\begin{array}{l}* \\
\ddot{\theta}\end{array}$ \\
\hline 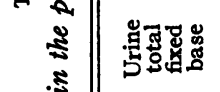 & 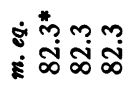 & 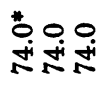 & 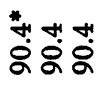 & 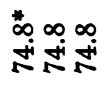 & : & 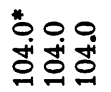 & ?ִ \\
\hline ฟิ & s் & $\ddot{g} \dot{y}$ & 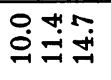 & 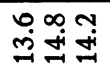 & กี่ & 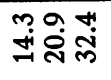 & वิ \\
\hline 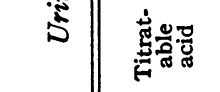 & 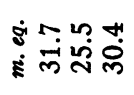 & กับ & 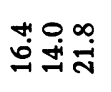 & 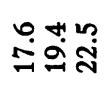 & $\ddot{m} \stackrel{+}{i}$ & 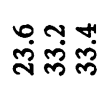 & 윰유 \\
\hline 喜宫 & 我亩 & $\stackrel{\infty}{\infty} \stackrel{\infty}{\min }$ & 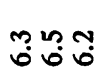 & 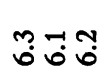 & 足 & 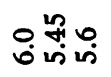 & "7 \\
\hline 题官首 & 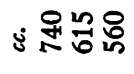 & 윰 & ஃั. స్తి & ณ 용 & นึกุ & 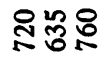 & 욝융윰 \\
\hline 窟蒿 & 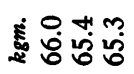 & น & ชิํํำ & ๓ำ & 象 & 我递审 & $\begin{array}{l}\infty \\
\ddot{8}: \infty \\
\dot{8}\end{array}$ \\
\hline Aّ & 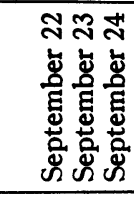 & 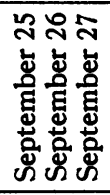 & 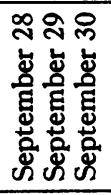 & 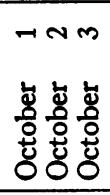 & 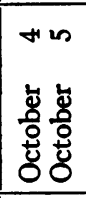 & 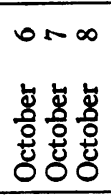 & 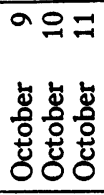 \\
\hline 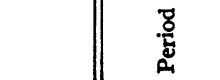 & $\mapsto$ & $\Xi$ & ヨ & $\geq$ & $>$ & 5 & 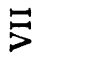 \\
\hline
\end{tabular}


LOEB, ATCHLEY, RICHARDS, BENEDICT AND DRISCOLL

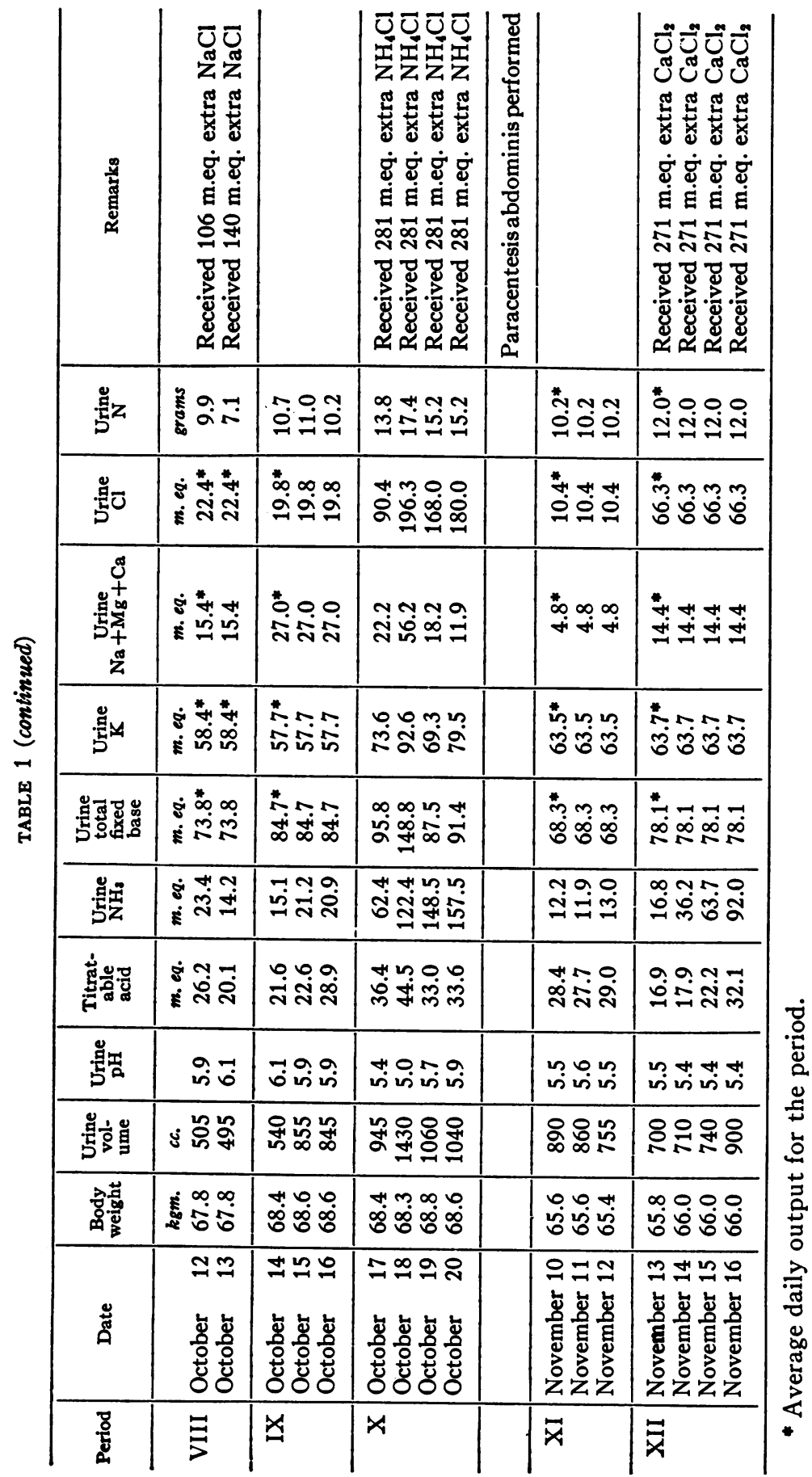


$+\mathrm{Ca}$, or on the excretion of $\mathrm{Cl}$. The $\mathrm{K}$ excretion in this and the following period seemed to be slightly decreased. The $\mathrm{pH}$ of the urine was not influenced. The patient gained $1.8 \mathrm{kgm}$. as a result of the $\mathrm{NaCl}$ ingestion. The difference between this edematous patient's physiological response to the ingestion of the $\mathrm{K}$ and $\mathrm{Na}$ salts of the same acid is indeed impressive. In the case of $\mathrm{KCl}$, the cation and anion were both eliminated, the former more rapidly than the latter. This phenomenon may perhaps be explained by the much greater relative rate of "reabsorption" of the chloride ion in the tubules of the kidney. Differences in ionic mobilities will not explain the differential rate of excretions of the $\mathrm{K}$ and $\mathrm{Cl}$ ions, as they are almost identical. Chloride given with the cation $\mathrm{Na}$ was not excreted at all.

Effect of the ingestion of $\mathrm{NH}_{4} \mathrm{Cl}$. During the four days of period $\mathrm{X}$ the patient was given $281 \mathrm{~m}$. eq. of $\mathrm{NH}_{4} \mathrm{Cl}$ daily. The excretion of $\mathrm{NH}_{3}$ and of $\mathrm{Cl}$ rose enormously. On the second day of administration of $\mathrm{NH}_{4} \mathrm{Cl}$, the excretion of potassium increased about $25 \mathrm{~m}$. eq. above the average for the control periods and the combined base fraction $\mathrm{Na}+\mathrm{Mg}$ $+\mathrm{Ca}$ increased about $40 \mathrm{~m}$. eq. and then fell in spite of the well sustained excretion of $\mathrm{NH}_{3}$ and $\mathrm{Cl}$. It is of interest to note in this patient that no diuresis resulted from the administration of large doses of $\mathrm{NH}_{4} \mathrm{Cl}$ and that the loss of fixed base from the body was minimal in spite of a marked lowering of the bicarbonate in the blood (to $20.0 \mathrm{~m}$. eq. per liter).

Effect of the ingestion of $\mathrm{CaCl}_{2}$. In period XII of the observations, the patient received $271 \mathrm{~m}$. eq. of $\mathrm{CaCl}_{2}$ daily for four days. As in the case of $\mathrm{NH}_{4} \mathrm{Cl}$ administration, there was an increase in $\mathrm{NH}_{3}$ and titratable acid excretion and a definite increase in $\mathrm{Cl}$ output by the kidneys but the changes were much less marked, as is seen in Table 1 and Figure 1. After four days, the concentration of $\mathrm{HCO}_{3}{ }^{\prime}$ in the blood serum fell from 27.5 to $13.5 \mathrm{~m}$. eq. per liter without diuresis or a significant loss of fixed base from the body.

It is of interest that stools collected for two days during the period of $\mathrm{CaCl}_{2}$ feeding contained $209 \mathrm{~m}$. eq. of $\mathrm{Ca}$ daily, whereas the total calcium excreted daily by the kidneys in this period was only $1.8 \mathrm{~m}$. eq. a day. In the control foreperiod XI the daily urinary $\mathrm{Ca}$ excretion was only $0.2 \mathrm{~m}$. eq., a very low value indeed.

Effects of various electrolytes on the blood serum. Chloride administered as $\mathrm{KCl}, \mathrm{NH}_{4} \mathrm{Cl}$ or $\mathrm{CaCl}_{2}$ caused an increase in $\mathrm{Cl}$ concentration in the serum and the two latter salts when given in massive doses over some days caused a significant fall in bicarbonate. In spite of the acidosis induced by $\mathrm{NH}_{4} \mathrm{Cl}$ and $\mathrm{CaCl}_{2}$ no diuresis resulted. This might be attributed to the low concentration of base present in the serum as seen in Table 2. Albright and Bauer (17), in a detailed study of a patient with chronic nephrotic edema, concluded that diuresis was brought about by raising the base concentration above a critical level. Peters expressed 
LOEB, ATCHLEY, RICHARDS, BENEDICT AND DRISCOLL

TABLE 2

Blood serum studies on the patient with chronic nephritis

\begin{tabular}{|c|c|c|c|c|c|c|}
\hline Date & $\begin{array}{l}\text { Total } \\
\text { base }\end{array}$ & Potassium & $\begin{array}{c}\text { Bicarbo- } \\
\text { nate }\end{array}$ & Chloride & $\begin{array}{c}\text { Serum } \\
\text { protein }\end{array}$ & Remarks \\
\hline & $\begin{array}{l}\text { m. eq. per } \\
\text { liter }\end{array}$ & $\begin{array}{l}\text { m. eq. per } \\
\text { liter }\end{array}$ & $\begin{array}{l}\text { m. eq. per } \\
\text { liter }\end{array}$ & $\begin{array}{l}\text { m. eq. per } \\
\text { liter }\end{array}$ & per cent & \\
\hline $10-5$ & 146.5 & 5.5 & 26.7 & 107.0 & 3.4 & $\begin{array}{l}\text { After receiving } 111 \mathrm{~m} \text {. eq. } \\
\mathrm{KCl} \text { on October } 4 \text {, } \\
1931\end{array}$ \\
\hline $10-19$ & 148.0 & 4.4 & 20.0 & 109.2 & 4.0 & $\begin{array}{l}\text { After receiving } 281 \mathrm{~m} \text {. eq. } \\
\mathrm{NH}_{4} \mathrm{Cl} \text { daily for } 3 \text { days }\end{array}$ \\
\hline $11-12$ & 145.9 & & 27.5 & 101.0 & 3.0 & $\begin{array}{l}\text { At end of control period } \\
\text { XI }\end{array}$ \\
\hline $11-17$ & 145.0 & & 13.5 & 116.6 & 3.4 & $\begin{array}{l}\text { After receiving } 271 \mathrm{~m} \text {. eq. } \\
\mathrm{CaCl}_{2} \text { for } 4 \text { days }\end{array}$ \\
\hline
\end{tabular}

the same opinion. Osman $(18,19)$ has made similar observations but an interpretation of his results is confused by the fact that sodium and potassium bicarbonates were administered simultaneously and by the fact that no serum base measurements were made. While the low concentration of base in the serum may be a factor in the inability of patients to excrete sodium chloride, this alone cannot be considered the determining factor, as the writers have observed a diabetic patient, whose serum base was reduced to $146.5 \mathrm{~m}$. eq. per liter, become markedly dehydrated while excreting over $200 \mathrm{~m}$. eq. of sodium in the course of twentyfour hours. In another diabetic $117.6 \mathrm{~m}$. eq. of sodium and magnesium determined together were excreted in twenty-four hours, while the concentration of inorganic base in the blood serum was $146.8 \mathrm{~m}$. eq. per liter. The serum protein concentration was normal in both of these patients. It is possible that when the inorganic base level of the blood serum is markedly reduced and when the concentration of protein in the serum is simultaneously found to be low, difficulties in water and sodium excretion exist. This statement offers no explanation but would seem to indicate that the problem deserving further study is that of the factors which determine the conditions under which the sodium ion may be excreted by the kidney.

\section{PART 2. THE STUDY OF ELECTROLYTE BALANCES IN A NORMAL ADULT}

There are numerous studies on the effects of various electrolytes upon human subjects in health and in disease. Because of the tediousness of prolonged balance studies and the technical difficulties encountered in making complete and simultaneous analyses of food, urine, stools and blood, most of the reports are inconclusive. For this reason and for the purpose of comparison of the behavior of the normal with the diseased human subject under various conditions we have made detailed observa- 
tions on several normal young men over long periods of time. The results of one of these studies are presented below. Observations in this case were made on the response to the ingestion of potassium chloride, sodium chloride and ammonium chloride as in the patient suffering from nephrosis already described.

\section{Details of the experiment}

E. F., number 316121 . The subject was a healthy unemployed adult white male of 23 whose only illnesses in the past were pneumonia five years before admission and a sore throat three years ago. On physical examination he was well developed and well nourished though lean, but no abnormalities were noted. Routine blood counts and urine examinations were normal. During the course of the experiment, which lasted 45 days, the patient remained in bed except for six hours a day when he was permitted to sit in a chair and to walk a few steps. He was placed on a standard diet immediately after admission and ate identical meals each day throughout the period of observation. There was never any return of food to the kitchen and there was at no time diarrhea. The diet was calculated to contain 85 grams protein and enough carbohydrate and fat to make a total of 2645 calories. The amount of fluid added to the diet was constant. Every five days when fresh foods were obtained, a complete duplicate day's diet was analyzed for fluid content, total inorganic base, $\mathrm{K}, \mathrm{Ca}, \mathrm{Na}+\mathrm{Mg}$ by difference, $\mathrm{Cl}, \mathrm{P}$ and total $\mathrm{N}$. The urine was analyzed daily for titratable acid, $\mathrm{NH}_{3}$, total inorganic base, $\mathrm{K}, \mathrm{Ca}, \mathrm{Na}+$ $\mathrm{Mg}$ by difference, $\mathrm{Cl}, \mathrm{P}$, inorganic $\mathrm{SO}_{4}$, total $\mathrm{N}$, organic acids and creatinine. $\mathrm{pH}$ determinations were also made daily. The stools were collected in fiveday periods and at the end of each period an enema of $500 \mathrm{cc}$. of distilled water was given. The stools were then analyzed for total inorganic base, $\mathrm{K}$, $\mathrm{Na}+\mathrm{Mg}$ by difference, $\mathrm{Cl}, \mathrm{P}$, and total $\mathrm{N}$. Blood studies were made from time to time, the blood being taken without stasis and delivered as usual under oil. All analyses were made in duplicate throughout the experiment.

\section{RESULTS}

The foreperiod. After the patient had been on the standard regime for a period of seven days, analyses were begun and were made daily for six days more as may be seen in Table 3 and Figure 2 . The chief point of interest is the extraordinary constancy of the urinary findings in this normal individual in contrast to the wider fluctuations seen in the nephrotic patient.

The effect of the ingestion of $\mathrm{KCl}$. After the completion of the foreperiod, the patient was given $201 \mathrm{~m}$. eq. of $\mathrm{KCl}$ on one day and on the subsequent day $134 \mathrm{~m}$. eq. It may be seen from Table 3 and Figure 2 that the effects were similar to those observed in the nephrotic patient. On the first day of $\mathrm{KCl}$ administration there was an abrupt increase in the $\mathrm{pH}$ of the urine and a drop in the titratable acid, with perhaps a slight decrease in the $\mathrm{NH}_{3}$ excreted. On the following two days, the $\mathrm{pH}$ decreased and the titratable acid rose above the levels of the control period. These changes, as in the case of the nephrotic patient, were related to differences in the rate of excretion of the $\mathrm{K}$ and $\mathrm{Cl}$ ions. On 


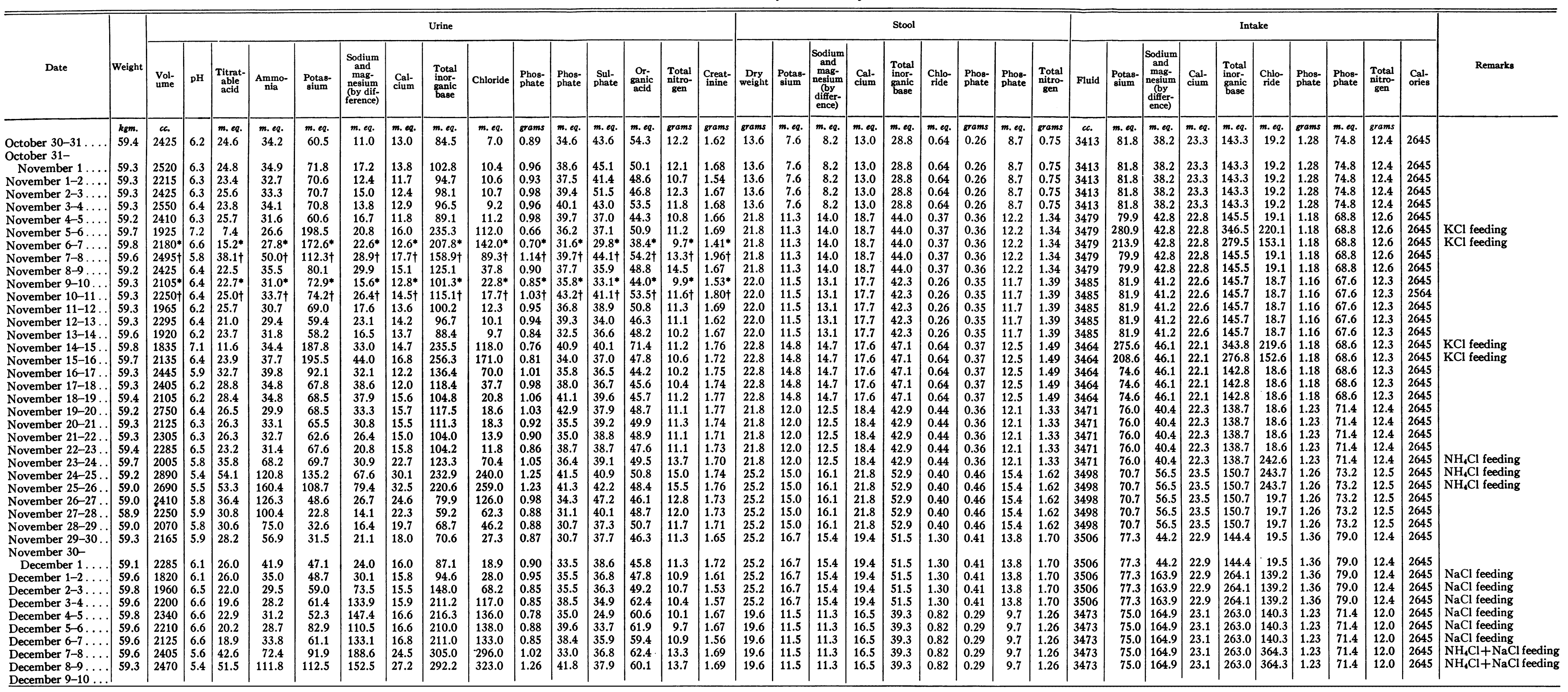

* Twenty-two hour urine specimen

$\dagger$ Twenty-six hour urine specimen. 
the first day of $\mathrm{KCl}$ ingestion, 70.9 per cent of the $\mathrm{K}$ ingested was excreted in the urine, whereas only 51 per cent of the $\mathrm{Cl}$ was eliminated in that time. During the next twenty-four hours, some of the chlorine which had been retained was excreted, so that at the end of 48 hours of $\mathrm{KCl}$ administration 78.6 per cent of the ingested $\mathrm{K}$ and 74.5 per cent of the $\mathrm{Cl}$ were recovered in the urine. In the days following the ingestion of

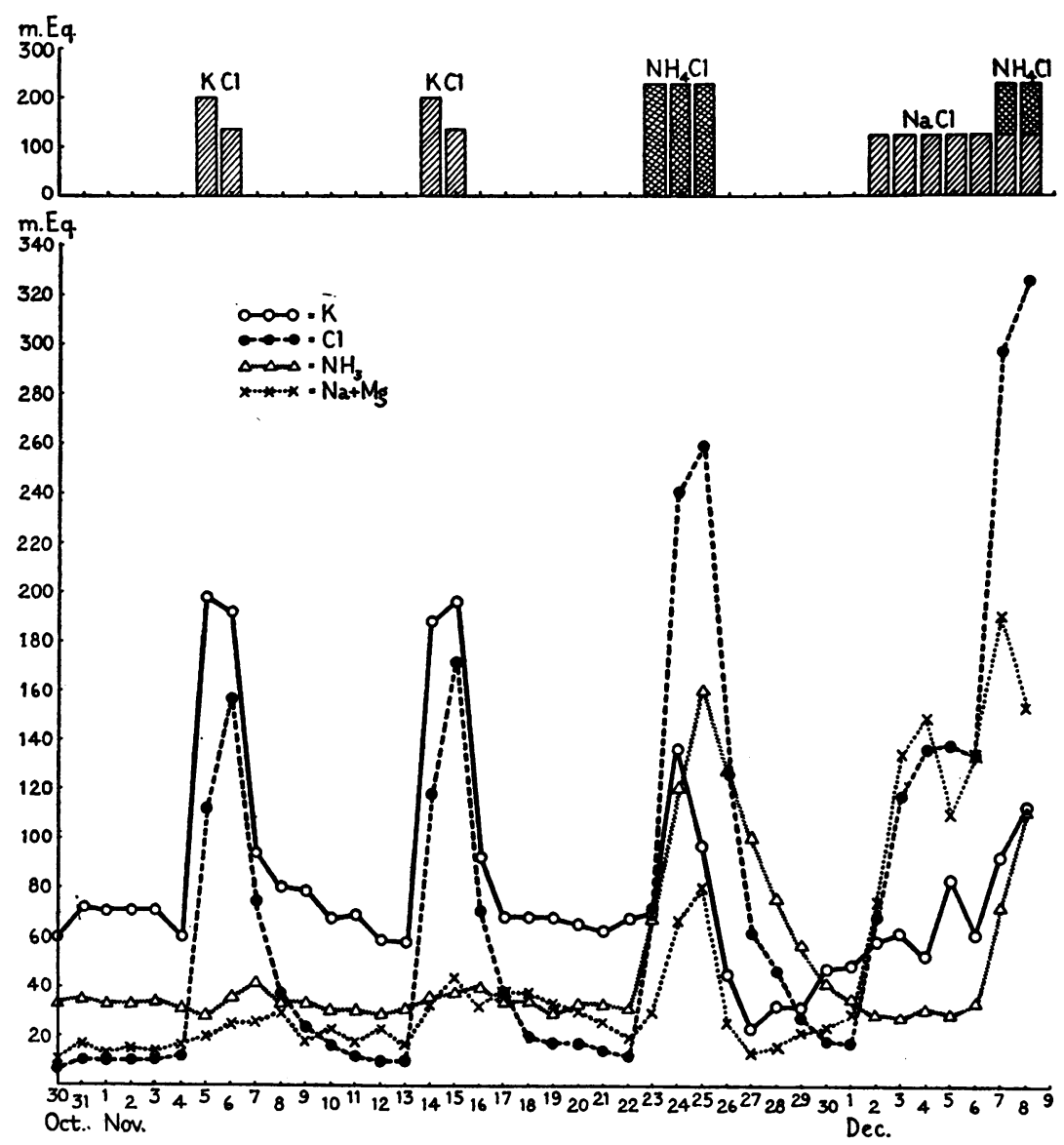

Fig. 2. Urinary Response of the Normal Subject to the Ingestion of VARIOUS ELECTROLYTES

$\mathrm{KCl}$ there was a slight increase in the excretion of base fraction $\mathrm{Na}+\mathrm{Mg}$ in the urine. This continued until the extra chloride ingested was completely excreted. While small in amount this base was presumably taken from tissue fluids to neutralize the acidifying action of the $\mathrm{Cl}$ ion, as during a period of nine days 10.0 per cent of the $\mathrm{K}$ ingested was excreted in the stool daily (exactly as in the foreperiod), whereas $\mathrm{Cl}$ absorption was more complete, only 0.5 per cent appearing in the stool each day, 
thus increasing the amount to be removed by the kidneys. The lag in excretion of the $\mathrm{Cl}$ ion was slightly less in this normal subject than in the nephrotic but otherwise the responses of the two individuals were alike.

In view of the fact that on two occasions in this period the urine specimens were collected in 22 and then 26 hour specimens, they were corrected by the creatinine excretion to a basis of 24 hours for presentation in Figure 2. In order to be certain that this did not vitiate the results, the whole $\mathrm{KCl}$ experiment was repeated with essentially the same results. On the first day, 68.2 per cent of the $\mathrm{K}$ and only 53.8 per cent of the $\mathrm{Cl}$ were excreted. After 48 hours, 79.2 per cent of the $\mathrm{K}$ ingested and 77.6 per cent of the $\mathrm{Cl}$ had been excreted in the urine. The changes in $\mathrm{pH}$ and titratable acid excretion were almost identical with the preceding experiment and the delayed increase in excretion of the base fraction $\mathrm{Na}+\mathrm{Mg}$ secondary to greater absorption of $\mathrm{Cl}$ than $\mathrm{K}$ from the gut was again noted. In this instance the daily per cent of $\mathrm{K}$ lost through the stools was 12.1 per cent while only 1.0 per cent of the $\mathrm{Cl}$ ingested was recovered from the feces. In each of the two experiments with $\mathrm{KCl}$ there was a gain of $0.5 \mathrm{kgm}$. in weight without corresponding retention of sodium during the two days of administration of the salt with a gradual loss to the level of the foreperiod in the following seven days. The reason for this slight gain in weight is not apparent.

The effect of the ingestion of $\mathrm{NH}_{4} \mathrm{Cl}$. The normal subject was given $224 \mathrm{~m}$. eq. of $\mathrm{NH}_{4} \mathrm{Cl}$ daily for three days. The results of this experiment seen in Table 3 and Figure 2 are qualitatively like those observed in the edematous nephritic and essentially like those described by Gamble et al. (20), Følling (21) and others. Thus, there was an increase in the excretion of $\mathrm{NH}_{3}$ which in the present study accompanied an increase in the excretion of fixed base (instead of following it as in the case of Gamble's and F $\phi$ lling's studies). The excretion of potassium reached its peak on the second day of $\mathrm{NH}_{4} \mathrm{Cl}$ feeding and dropped on the third day, whereas the excretion of the base fraction $\mathrm{Na}+\mathrm{Mg}$ was slightly higher on the third day. It will be observed above in the study of the patient with edema that there was also slight augmentation in excretion of $\mathrm{K}$ and of the fraction $\mathrm{Na}+\mathrm{Mg}+\mathrm{Ca}$, most marked on the second day. In both the normal and nephritic subjects, retention of the $\mathrm{Cl}$ ion on the first day of $\mathrm{NH}_{4} \mathrm{Cl}$ administration was marked. There was a great increase in calcium excretion through both the gut and the kidneys, in the normal subject. In the days following the ingestion of $\mathrm{NH}_{4} \mathrm{Cl}$, potassium was retained without appreciable storage of the base fraction $\mathrm{Na}+\mathrm{Mg}$ while the excretion of $\mathrm{NH}_{3}$ and of $\mathrm{Cl}$ remained above the normal level until the balances were practically restored on the fifth day. On the first day of $\mathrm{NH}_{4} \mathrm{Cl}$ feeding there was a gain of $0.3 \mathrm{kgm}$. followed by a diuresis and loss of $0.8 \mathrm{kgm}$. and at the end of the period the weight reached its normal 
level. (The "recovery" period following the ingestion of $\mathrm{NH}_{4} \mathrm{Cl}$ was not studied in the patient with nephrosis.)

The effect of the ingestion of $\mathrm{NaCl}$. One hundred and twenty $\mathrm{m}$. eq. of $\mathrm{NaCl}$ were added to the diet of this normal adult who had been on a "salt-poor" regime $(\mathrm{Na}+\mathrm{Mg}$ of the diet averaged about $45 \mathrm{~m}$. eq. daily) for seven weeks. In the first forty-eight hours he retained 185.4 m. eq. or 56.6 per cent of the ingested $\mathrm{Na}+\mathrm{Mg}$ and $181 \mathrm{~m}$. eq. or 65.1 per cent of the $\mathrm{Cl}$ of the diet with a gain of $0.7 \mathrm{kgm}$. in weight. In the next four days of $\mathrm{NaCl}$ administration he was in exact balance when compared with the original foreperiod in which there was a positive $\mathrm{Na}+\mathrm{Mg}$ balance of $15 \mathrm{~m}$. eq. and a positive $\mathrm{Cl}$ balance of $8 \mathrm{~m}$. eq. daily, probably representing the diurnal skin loss of these ions. The $\mathrm{Na}$ and $\mathrm{Cl}$ retained during the first two days were not subsequently excreted. The response of this normal subject on the first two days of the "salt regime" was qualitatively like that of the edematous nephritic although the $\mathrm{NaCl}$ retention was less complete. It is interesting to note that this similarity of response to $\mathrm{NaCl}$ ingestion occurred in spite of the fact that the serum protein concentration in the normal subject was about double that of the nephrotic patient. It should be pointed out that as a result of $\mathrm{NaCl}$ administration a rise in the base content of the serum was accompanied by the passage of fluid from the blood to the tissue spaces, as evidenced by the retention of both water and $\mathrm{NaCl}$. This appears to be at variance with the suggestion of Albright and Bauer discussed above, that an increase in base level is associated with the process of diuresis. If this retention of $\mathrm{NaCl}$ and water with an increase in concentration of base in the serum could be shown to occur when the serum protein content is abnormally low, the inconsistency would be even more significant. Unfortunately no serum base determinations were made in our nephrotic patient during the period of $\mathrm{NaCl}$ administration.

On the last two days of the $\mathrm{NaCl}$ experiment, the normal subject was given $224 \mathrm{~m}$. eq. of $\mathrm{NH}_{4} \mathrm{Cl}$ in addition to his daily ration of $120 \mathrm{~m}$. eq. of $\mathrm{NaCl}$. This was done to see if he would lose fixed base before the augmentation of ammonia excretion, as in the studies of Gamble and of Følling, when an ample source of base was available. It will be seen in Table 3 and Figure 2 that, as in the previous experiments, this subject had a simultaneous increase in the elimination of base and $\mathrm{NH}_{3}$. The total loss of $\mathrm{K}, \mathrm{Na}, \mathrm{Mg}$ and $\mathrm{Ca}$ was practically identical when $\mathrm{NH}_{4} \mathrm{Cl}$ was given after a prolonged "salt-poor" regime with a lowered base concentration in the blood serum and when it was given after sufficient $\mathrm{NaCl}$ in the diet to raise the serum base to its normal level.

The effect of various electrolytes on the blood serum. In Table 4 it will be seen that the "low-salt regime" resulted in a decrease in the total inorganic base and $\mathrm{Cl}$ concentrations of the blood serum; no other significant deviations from the normal were observed. The administration 
TABLE 4

Blood serum studies on the normal subject

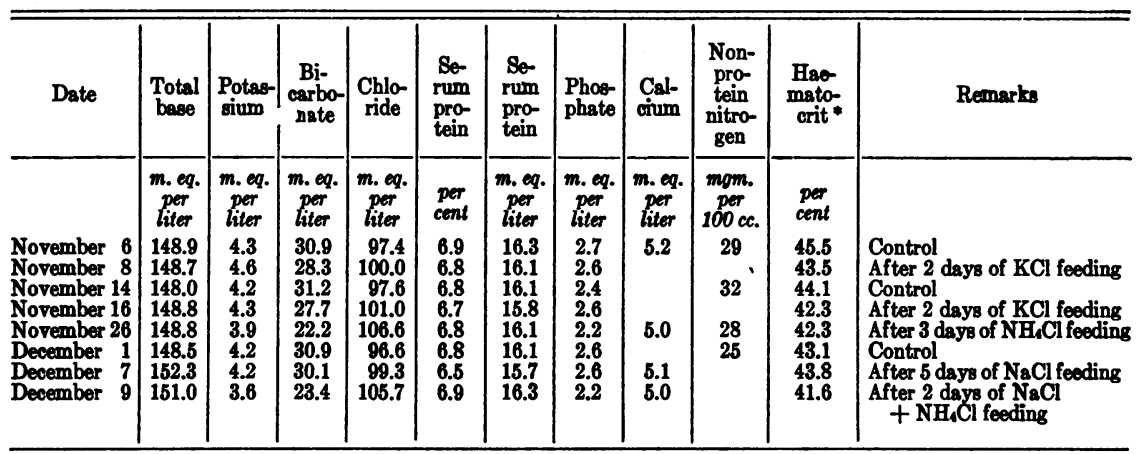

* Determined on whole blood.

of $\mathrm{KCl}$ in both instances resulted in a slight increase in the $\mathrm{Cl}$ content of the serum at the expense of bicarbonate. The feeding of $\mathrm{NH}_{4} \mathrm{Cl}$ resulted in the same qualitative change in the electrolyte pattern of the serum although quantitatively greater, the $\mathrm{Cl}$ increasing about $8 \mathrm{~m}$. eq. per liter while the $\mathrm{CO}_{2}$ decreased in an equivalent amount. The base concentration and water content were not changed. After six days of $\mathrm{NaCl}$ feeding, the concentration of base in the serum rose to the accepted normal level. When the base content of the serum had risen to a more normal value, the storage of $\mathrm{NaCl}$ and water in the body ended and the normal balance between ingestion and excretion had been re-established, but at a higher level of base in the serum than in the foreperiod when the patient was on the "low-salt" regime. The effects of $\mathrm{NH}_{4} \mathrm{Cl}$ on the blood serum were qualitatively and quantitatively alike whether the subject received large amounts of $\mathrm{NaCl}$ in his diet or whether he was on a "salt-poor" regime.

\section{DISCUSSION}

At least three groups of factors must be taken into consideration in any discussion of the mechanism of edema in the nephrotic form of chronic nephritis and in malnutrition. (1) The best understood of these is the decrease in osmotic pressure of the blood due to loss of proteins from the serum. (2) The second factor is that of the hydrostatic pressure differences between the capillaries and the tissue spaces. (3) The third factor and the least understood is that of the specific ionic excretory function of the kidney. In this term we include all the factors involved in the elimination of specific ions from the body, recognizing that such elimination seems to depend upon the particular nature of the ion itself and is largely independent of its osmotic effect. In other forms of edema variations in capillary permeability undoubtedly play an important rôle, 
but it does not appear necessary in the present state of our knowledge to implicate this factor in the explanation of nephrotic edema. As was stated in the introduction there have existed two schools of thought. One emphasizes the importance of specific kidney or tissue disturbances as evidenced by an apparent difference in behavior between the nephrotic and the normal individual upon the administration of certain electrolytes. The other group of investigators maintains that the abnormal accumulation of fluid and the behavior of the electrolytes can be explained solely on the basis of a decrease in oncotic pressure and assumes that the ionic excretory functions of the kidney are normal.

If it be assumed that the specific ionic excretory functions of the kidney are not disturbed in patients with nephrotic or nutritional edema, it is apparent that a decrease in oncotic pressure within the capillaries will tend to force an approximately normal intercellular fluid into the tissue spaces until the effective pressures and ionic concentrations on both sides of the capillary adjust themselves according to the Donnan equilibrium. It is obvious that an important factor in the accumulation of this excessive volume of interstitial fluid is the quantity of water and $\mathrm{NaCl}$ that is available; therefore the administration of $\mathrm{NaCl}$ to an individual with a decreased concentration of protein in his blood serum will cause an increased flow of physiological salt solution to the tissue spaces. This retention would naturally simulate interference with the ability of the patient to excrete $\mathrm{NaCl}$. A state of affairs, qualitatively similar, might be anticipated in a normal individual after the prolonged restriction of $\mathrm{NaCl}$ ingestion, resulting here from true base depletion. Furthermore, one would not expect to find a qualitative difference in response of the normal and nephrotic individual to the ingestion of $\mathrm{KCl}$ or $\mathrm{NH}_{4} \mathrm{Cl}$, as the nephrotic is assumed according to this hypothesis to possess normal specific ionic excretory functions.

The experiments described in this paper amply confirm this point of view. Thus, the nephrotic patient retained $\mathrm{NaCl}$ completely with a coincident increase in edema as evidenced by gain in weight. The normal subject after prolonged $\mathrm{NaCl}$ deprivation also retained salt and water for the first two days of sodium chloride feeding. The quantitative difference in the behavior of these two individuals can be easily explained by the difference in oncotic pressure of their sera. Furthermore, our studies show that there is no essential qualitative difference in the response of these two individuals to the ingestion of $\mathrm{KCl}$ or of $\mathrm{NH}_{4} \mathrm{Cl}$.

The facts presented in the foregoing discussion do not support the idea chiefly advanced by the school of Widal, Magnus-Levy and of Blum, that the determining abnormalities in nephrotic edema are to be found in specific ion disturbances of renal or tissue behavior.

The importance of the hydrostatic pressure within the capillaries in relation to edema needs no emphasis. Von Farkas (22), Mufson (23) 
and others have pointed out a relationship between the concentration of protein in the blood serum, the venous or capillary pressure in an extremity and the presence of edema. As would be expected, there appears to be a rough correlation which would suggest that the higher the pressures within the veins or skin capillaries, the more likely a patient is to become edematous with a given decrease in the serum protein concentration. Unfortunately, these measurements are of the crudest sort and are applicable only to a limited group of capillaries. Beyond these elementary facts, little is known of the relations of capillary pressures to edema of the nephrotic type.

While the qualitative similarity in response of the nephrotic and normal subjects to the ingestion of certain electrolytes has been demonstrated in the above studies, it should be clearly emphasized that the mechanism of nephrotic edema cannot be explained solely by alterations in the concentration of protein in the blood serum. For example, as was stated in the introduction and as we have observed in the nephrotic patient of the present study, there may be complete diuresis without significant change in the concentration of protein in the serum. Furthermore it is well recognized that diuresis may occur spontaneously or follow fever either induced artificially or due to infection.

In addition to these observations, apparently inconsistent with the hypothesis, certain theoretical difficulties should be mentioned. If a decreased oncotic pressure causes increased flow of fluid from the capillaries to the tissue spaces in the kidneys, one might expect increased filtration through the glomerular capillaries and ceteris paribus an increased urinary output, which is not the case. If, however, it were assumed that, in conditions leading to nephrotic edema, the rate of blood flow through the kidney or the capillary pressure in the glomeruli were reduced or if the reabsorption of water from the tubules were increased, these discrepancies could be harmonized with the theory. Of such changes and the possibility of actual renal damage we have no experimental evidence.

Another phenomenon for which the oncotic hypothesis offers no explanation is the well known diuretic effect of certain electrolytes such as potassium salts, $\mathrm{NH}_{4} \mathrm{Cl}$, and $\mathrm{CaCl}_{2}$. Although there is no qualitative difference in the behavior of the electrolytes $\mathrm{KCl}$ and $\mathrm{NH}_{4} \mathrm{Cl}$ when ingested by normal and nephrotic individuals, as shown by our studies, there may be great quantitative differences in the effect of these substances on various edematous individuals and upon the same individual at different times. While these differences have been ascribed to differences in base concentration in the blood, this point is not yet proved; there is also no simple correlation between diuresis and serum protein concentration. This problem is closely related to that of the kidney or tissue factors which regulate the excretion of the $\mathrm{Na}$ ion by the kidney. Until the physicochemical laws governing the excretion of various ions 
are understood, an evaluation of abnormalities present will remain difficult, since normal and nephrotic individuals may react to these ions in a qualitatively similar manner.

\section{CONCLUSIONS}

1. The responses of a normal individual on a "salt-poor" regime and of a patient with nephrotic edema to the ingestion of $\mathrm{KCl}, \mathrm{NH}_{4} \mathrm{Cl}$ and $\mathrm{NaCl}$ have been studied in balance experiments.

2. The following similarities in their behavior have been demonstrated:

(a) When $\mathrm{KCl}$ was fed to both patients the urine at first became alkaline, as the excretion of $\mathrm{K}$ was more rapid than that of $\mathrm{Cl}$. Then the urine became more acid and there was an increase in the excretion of $\mathrm{NH}_{3}$ and fixed base. This probably resulted from the fact that the absorption of $\mathrm{Cl}$ from the intestinal tract was greater than that of $\mathrm{K}, \mathrm{KCl}$ thus acting as an "acidifying salt."

(b) After feeding $\mathrm{NH}_{4} \mathrm{Cl}$ there was an increase in excretion of inorganic base and $\mathrm{NH}_{3}$ with retention of $\mathrm{Cl}$ causing a lowering of serum bicarbonate, as has been described by others. No significant diuresis occurred in these patients.

(c) After ingesting $\mathrm{NaCl}$, both the nephrotic patient and the normal subject retained $\mathrm{NaCl}$ and water. This retention was greatest in the edematous patient. After the base of the blood of the normal subject on a "salt-poor" regime had been raised to its normal level by $\mathrm{NaCl}$ administration, continued ingestion of this salt caused no further retention.

3. It is pointed out that the responses of nephrotic and normal individuals to these electrolytes are qualitatively alike. The quantitative differences observed are of great clinical importance and are probably to a large extent dependent upon differences in serum protein concentration.

4. A number of inconsistencies in the application of the oncotic hypothesis are discussed.

The authors wish to express their appreciation to Miss Natalie Bryan, Miss Marjorie Clark and Miss Evelyn Krueger for their technical assistance. They also wish to thank Miss Margaret Hawthorne and Miss Elise Stanley for their careful supervision of the nursing and dietetic problems arising in the course of this investigation.

\section{BIBLIOGRAPHY}

1. Widal, F., and Javal, A., J. de physiol. et de path. génér., 1903, v, 1199. La chlorurémie et la cure de déchloruration dans le mal de Bright. Étude sur l'action déchlorurante de quelques diurétiques.

2. Magnus-Levy, A., Ztschr. f. klin. Med., 1928, cvii, 659. Natrium- und Kaliumsalze bei Wassersucht. 
3. Magnus-Levy, A., Deutsche med. Wchnschr., 1920, xlvi, 594. Alkalichloride und Alkalikarbonate bei Oedemen.

4. Blum, L., et Van Coulaert, Le Rôle du sel dans les Néphrites. 1931. Masson et Cie., Paris.

5. Falta, W., and Quittner, M., Wien. klin. Wchnschr., 1917, xxx, 1189. Über den Chemismus verschiedener Ödemformen.

6. Starling, E. H., J. Physiol., 1896, xix, 312. On the Absorption of Fluids from the Connective Tissue Spaces.

7. Epstein, A. A., Am. J. Med. Sci., 1917, cliv, 638. Concerning the Causation of Edema in Chronic Parenchymatous Nephritis; Method for Its Alleviation.

8. Peters, J. P., Bruckman, F. S., Eisenman, A. J., Hald, P. N., and Wakeman, A. M., J. Clin. Invest., 1931, x, 941. The Plasma Protein in Relation to Blood Hydration. VI. Serum Proteins in Nephritic Edema.

9. Govaerts, P., Extrait des rapports du XIXe Congrès Français de Médecine-Paris, 1927, p. 63 (Masson et Cie.). Rôle des Proprietés Physicochimiques des Protéines dans la Pathogenie des Oedemes avec Étude des Variations de la Tension Osmotique et de la Tension Capillaire.

10. Schade, H., and Claussen, F., Ztschr. f. klin. Med., 1924, c, 363 . Der onkotische Druck des Blutplasmas und die Entstehung der renal bedingten Ödeme.

11. Leiter, L., Arch. Int. Med., 1931, xlviii, 1. Experimental Nephrotic Edema.

12. Barker, M. H., and Kirk, E. J., Arch. Int. Med., 1930, xlv, 319. Experimental Edema (Nephrosis) in Dogs in Relation to Edema of Renal Origin in Patients.

13. Weech, A. A., and Ling, S. M., J. Clin. Invest., 1931, x, 869. Nutritional Edema. Observations on the Relation of Serum Proteins to the Occurrence of Edema and to the Effect of Certain Inorganic Salts.

14. Meyer, Paul, Ztschr. f. klin. Med., 1931, cxv, 647. Untersuchungen über den kolloidosmotischen Druck des Blutes.

15. Atchley, D. W., Loeb, R. F., Benedict, E. M., and Palmer, W. W., Arch. Int. Med., 1923, xxxi, 611. Physical and Chemical Studies of Human Blood Serum. II. A Study of Twenty-nine Cases of Nephritis.

16. Van Slyke, D. D., Factors Affecting the Distribution of Electrolytes, Water and Gases in the Animal Body. Philadelphia, 1926, p. 40.

17. Albright, F., and Bauer, W., J. Clin. Invest., 1929, vii, 465. The Action of Sodium Chloride, Ammonium Chloride, and Sodium Bicarbonate on the Total Acid-Base Balance of a Case of Chronic Nephritis with Edema.

18. Osman, A. A., Guy's Hosp. Rep., 1926, lxxvi, 412. Preliminary Observations on the Treatment of Nephritis with Edema by Means of Large Doses of Alkalies.

19. Osman, A. A., Guy's Hosp. Rep., 1927, lxxvii, 386. Studies in Bright's Disease: The Use of Alkalies in the Treatment of Bright's Disease and Their Prophylactic Value in This and Other Conditions Associated with Impairment of Renal Function.

20. Gamble, J. L., Blackfan, K. D., and Hamilton, B., J. Clin. Invest., 1925, i, 359. A Study of the Diuretic Action of Acid Producing Salts.

21. Følling, A., Acta med. Skandinav., 1929, 1xxi, 221. On the Mechanism of Ammonium Chloride Acidosis.

22. von Farkas, G., $Z$ tschr. f. d. ges. exper. Med., 1928, 1xii, 35. Ist das Ödem ein Resultat der Capillarsekretion? 
23. Mufson, I., Am. J. Med. Sci., In press. A Study of the Capillary Pressure in Nephritis and Hypertension.

24. Atchley, D. W., and Benedict, E. M., J. Biol. Chem., 1927, 1xxiii. I. The Distribution of Electrolytes in Dogs Following Ligation of Both Ureters.

25. Clark, E. P., and Collip, J. B., J. Biol. Chem., 1925, lxiii, 461. A Study of the Tisdall Method for the Determination of Blood Serum Calcium with a Suggested Modification.

26. Tisdall, F. F., and Kramer, B., J. Biol. Chem., 1921, xlviii, 1. Methods for the Direct Quantitative Determination of Sodium, Potassium, Calcium and Magnesium in Urine and Stools.

27. Van Slyke, D. D., and Palmer, W. W., J. Biol. Chem., 1920, xli, 567. Studies of Acidosis. XVI. The Titration of Organic Acids in Urine.

28. Van Slyke, D. D., J. Biol. Chem., 1917, xxxii, 455. Studies of Acidosis. VII. The Determination of B. Hydroxybutyric Acid, Aceto-Acetic Acid, and Acetone in Urine.

29. Folin, O., Ztschr. f. physiol. chem., 1904, xli, 223. Beitrag zur Chemie des Kreatinins und Kreatins im Harne.

30. Van Slyke, D. D., and Neill, J. M., J. Biol. Chem., 1924, lxi, 523. The Determination of Gases in Blood and Other Solutions by Vacuum Extraction and Manometric Measurement.

31. Folin, O., and Wu, H., J. Biol. Chem., 1919, xxxviii, 81. A System of Blood Analysis.

32. Fiske, C. H., J. Biol. Chem., 1921, xlvii, 59. The Determination of Inorganic Sulfate, Total Sulfate and Total Sulfur in Urine by the Benzidine Method.

33. Gamble, J. L., Ross, G. S., and Tisdall, F. F., J. Biol. Chem., 1923, Ivii, 633. The Metabolism of Fixed Base during Fasting.

34. Van Slyke, D. D., Wu, H., and McLean, F. C., J. Biol. Chem., 1923, lvi, 765. Studies of Gas and Electrolyte Equilibria in the Blood. V. Factors Controlling the Electrolyte and Water Distribution in the Blood. 